\title{
Celsus, Toledot Yeshu and early traces of apology for the virgin birth of Jesus
}

\author{
ANTTI LAATO
}

\begin{abstract}
In this article New Testament passages referring to the birth of Jesus are related to Celsus' antiChristian arguments and the Jewish Toledot Yeshu tradition with a new question: Why it was so difficult to speak about the virgin birth of Jesus? It is argued that the concept of the virgin birth of Jesus was seen to be problematic for two reasons: 1) The concept was liable to result in scurrilous rumours, even scoffing and parodic episodes revolving on its sexual aspects. 2) Every attempt to explain that God was in some way the agent when a young girl conceived came too close to Gen. 6:1-4 - the text which explained in ancient Judaism the origin of the demonic world. Therefore, some New Testament authors (for example, the writer of the Gospel of John) deliberately avoided speaking about the virgin birth and instead presented the birth of Jesus in terms of the idea of an incarnated, personified, divine Wisdom. In order to avoid erroneous connotations relating to Gen. 6:1-4, Matthew and Luke followed a tradition where the Holy Spirit (a feminine word in Hebrew and Aramaic) played an active role in the pregnancy.
\end{abstract}

\section{New question}

The miraculous birth of Jesus to the Virgin Mary is an essential belief in the Christian Church.* Exegetical discussions have mainly focused on the problems concerning the origin of idea of virginal birth and its meaning in the early Christian belief system. It is argued that Paul did not know about Jesus' virgin birth, it being formulated only later in the Gospels of Matthew and Luke (e.g. Matlock 2000: 45-57; Brown 1993). The witness statements of these two gospels of the birth of Jesus by the Virgin Mary soon became the cornerstone of the Christian faith (see for example Gambero 1999). In scholarly discussion new ideas can emerge when new questions are presented on the material. In this article I shall re-evaluate the New Testament references to the birth of Jesus by suggesting that the main question is not 'When and why was the idea of the

* This article was written in 20 I 5 when I was granted Professor Pool scholarship by the Society of Swedish Literature in Finland that is hereby gratefully acknowledged. 
virgin birth introduced?' but rather Why it was so difficult to speak about the virgin birth of Jesus? The relevance of this question becomes apparent when one notices that the virgin birth is not mentioned in the Gospel of John even though it was certainly written after Matthew and Luke, and the concept itself would have fitted well into the framework of the high Christology of that gospel. ${ }^{1}$

The new question presented here implies that there were reasons as to why the concept of the virgin birth was so difficult. From at least two different perspectives the concept was open to criticism. Firstly, common sense indicates that a young girl cannot conceive without the help of a man. Every attempt to argue in that direction laid the story open to scurrilous rumours, even scoffing and parodic episodes revolving on the sexual aspects of the situation. The relevance of this problem is well attested in early anti-Christian critiques of the virgin birth, documented from the second century AD onwards (in the text of Celsus, as quoted in Origen's Contra Celsum) and manifest in the so-called Jewish Toledot Yeshu literature. A second and more serious problem is that every attempt to explain that God was in some way the agent in the case of a young girl conceiving came too close to Gen. 6:I-4. This text was understood in early Judaism to explain the origin of the demonic world, as becomes clear from First Enoch (Hanson I 977, Nickelsburg I 977, Bhayro 2005 and 2006) and the Book of Jubilees (VanderKam r 999). ${ }^{2}$ Therefore, all expressions concerning the virgin birth where the activity of God was emphasized came dangerously close to blasphemy against God. The relevance of this problem becomes apparent in the formulations of the virgin birth in Matthew and Luke where no reference is made to the agency of God the Father in the pregnancy of Mary; rather to that of the Holy Spirit (a feminine word in Hebrew and Aramaic). Starting from these two difficulties I shall discuss how the concept of the birth of Jesus is presented in the New Testament texts.

1 The Gospel of John emphasizes three important elements in Christology. I) Jesus is the Son of God who had pre-existence before his advent. The world is created through him (John I:I-I4). 2) God sent his Son to the world in order to save it from sin (John 3:I6-I7).3) After his resurrection Jesus took up his glorious position beside God in heaven (cf., Ps. I Io: I) where he reigns over the world. Against the background of such high Christology it would be curious if the writer of the Gospel of John thought that Jesus' birth was an ordinary event. However, all the three Christological elements are already represented in the theology of Paul: I) I Cor. 8:6; Phil. 2:5-IO; 2) the 'God sent his Son' formula in Rom. 8:3; Gal. 4:4 (cf., John 3:I 6-I 7; I John 4:9-Io); 3) I Cor. I 5:25-7 with reference to Psalm I ro. For these connections between John and Paul see Hengel I 992: 425-48.

2 See further the contributions in Fröhlich and Koskenniemi 2013. 


\section{Toledot Yeshu literature: a parodic counter-narrative to the Gospels}

A good example of parodic treatment of the virgin birth of Jesus can be found in the Toledot Yeshu (TY) literature. It consists of Jewish counter-narratives to the Christian Gospels where the case of Jesus is revealed to Jewish readers in a parodic way. ${ }^{3}$ Research into the TY tradition has benefitted enormously from the recent publication of a comprehensive edition of the various TY stories. ${ }^{4}$ It is a well known fact that in its literary form the TY tradition was produced only from the Byzantine period onwards - something which was emphasized in Samuel Krauss's monograph of 1902 and has recently been confirmed in several articles edited by Peter Schäfer, Michael Meerson and Yaacov Deutsch (201 I; see also Schreckenberg I999: 483-4). Meerson and Schäfer (2014, I: 6-7) argue that Agobard's (c. $769-84 \mathrm{O} \mathrm{CE})$ reference to a Jewish story about Jesus is the earliest clear example of the existence of a written version of the TY (see also Schäfer 20 I : 27-48) - in that case the tradition which is similar to that in Aramaic documents from Cairo Geniza (corresponding to the tradition of the Early Oriental A in Group I). They admit that some independent Jewish counter-arguments concerning the life of Jesus are detectable in patristic literature, but argue that none of them contain such details that will prove that a written version of the TY tradition ever existed. For example, Celsus' Jewish source on Jesus was not a TY version. The only real parallels to the TY tradition are provided in the Talmud which calls Jesus the son of Panthera, and contains stories about the trial of five disciples of Jesus (bSanh 43a), Jesus' atrocious behaviour in an Alexandrian hostel (bSanh ro $\mathrm{b}$ ) and Miriam's confession to Rabbi Aqiba concerning Yeshu's parentage (Kallah I8b). (See Schäfer 2007: $34-40,75-8$ I)

The central topic in the TY tradition was the means by which Mary became pregnant. It was presented in a parodic way. Precisely this detail in TY has been the topic of earlier counter-exegetical arguments against Christianity, especially in Celsus' Jewish source where reference is also made to Jesus as the son of Panthera (Contra Celsum I.2 8, 32, 33, 69). ${ }^{5}$ David Rokéah and Philip Alexander

3 Concerning the genre of counter-narrative in Jewish sources, see Funkenstein 1993 and Biale 1999. Concerning the use of parody in Jewish texts from late antiquity see Zellentin 20r r. Holger Zellentin deals with rabbinical parodies about Christians or Jesus on pp. I37-2 I 2.

4 See Meerson and Schäfer 20I 4. In Meerson and Schäfer (20 I4, I: 28-39) all available manuscripts have been divided into three different main Groups I-III. Group I 'represents the earliest developments of all of the the Toledot Yeshu versions' (I:3 I).

5 Scholars have discussed whether or not Celsus has fabricated his Jewish sources as Origen states (see I.28, 34, 44, 49, 55, 67; II. I, 28, 3 I , 34, 53). For example Meerson 
have argued that the idea of Jesus as the son of Pandira/Panthera was developed in Yabneh during the second century вс (Rokéah 2002: I 2, 40n37, I07-8, I I 8; Alexander 20i i: 599-600). According to Nicholas de Lange, the fables about Jesus which Celsus' Jew formulated were later used in the TY tradition. ${ }^{6}$ Even other Jewish counter-exegetical arguments used by Celsus are similar to those which were later presented in early versions of the TY literature. ${ }^{7}$ Alexander in the study referred to above has suggested that TY literature should be regarded as one relevant apocryphal viewpoint on the four gospels which may add to our understanding of the early traditions about Jesus. What kind of interpretive scenario does the TY tradition and its pre-stages in Celsus's text and rabbinical writings give to the birth of Jesus?

\section{Mary's harlotry with Panthera}

In his work Contra Celsum Origen explains that Celsus would have used an early (Alexandrian) Jewish source in which Jesus was presented as the son of Mary and the Roman soldier Panthera. ${ }^{8}$ According to Origen, Celsus claims to

and Schäfer (2014, I: 7n25) emphasize that 'it is impossible to ascertain whether or not Celsus' Jew was a fictive character'. Nevertheless, several scholars have argued that Celsus must have known Jewish sources. For this see Niehoff 2013. She does not refer to the Toledot Yeshu tradition apparently because she has evaluated the situation in such a way that all references to it would be anachronistic. See further Bammel I986: 26583; Baumgarten I 990: 37-44; Hargis I 999: 36-9; Triggs I 998: 58. See also Blummell 2007: 297-31 5 where he notes that 'it is impossible to determine whether Celsus' Jew was a real person' (p. 309), but he nevertheless argues that views presented by this possible 'conglomeration of many Jews' differ from those otherwise presented by Celsus. See p. 299: '... there are compelling reasons to believe that embedded within Celsus' True Doctrine are authentic Jewish arguments against Christianity from the latter part of the $2^{\text {nd }}$ century'.

6 De Lange I 978: 66: 'Celsus next puts forward, in the person of a Jew, some of the fables about Jesus which were already current, and were later woven together to form the Sepher Toldoth Yeshu.' See also p. 69: 'It is an early source for the slanders against Jesus which appear in the Sepher Toldoth Yeshu but have left little trace in the tannaitic writings and the earliest of the Church Fathers'. See further also Meerson and Schäfer 20I4, I: $5-8$.

7 These parallels I shall deal with in another article; 'A cold case reopened: a Jewish source on Christianity used by Celsus and the Toledot Yeshu literature. From counterexegetical arguments to full-blown counter-story'.

8 Methodologically we must be aware of the fact that Celsus' text is not given; rather it must be reconstructed. Concerning the attempts to reconstruct Celsus' text the following works and translations (where Celsus' quotations are marked) should be mentioned; see Bader I 940, Chadwick I953, Hoffman I987, Lona 2005. In this recon- 
have used a Jewish source in which a Jew engages in a personal dialogue with Jesus (I.28). On this occasion Origen paraphrases Celsus' text where the latter has used his Jewish source and presents the following details about the birth and the life of Jesus are presented:

For he [i.e. Celsus's Jewish informant] represents him disputing with Jesus, and confuting Him, as he thinks, on many points; and in the first place, he accuses Him of having invented his birth from a virgin, and upbraids Him with being born in a certain Jewish village, of a poor woman of the country, who gained her subsistence by spinning, and who was turned out of doors by her husband, a carpenter by trade, because she was convicted of adultery; that after being driven away by her husband, and wandering about for a time, she disgracefully gave birth to Jesus, an illegitimate child (skotios), who having hired himself out as a servant in Egypt on account of his poverty, and having there acquired some miraculous powers, on which the Egyptians greatly pride themselves, returned to his own country, highly elated on account of them, and by means of these proclaimed himself a God. Now, as I cannot allow anything said by unbelievers to remain unexamined, but must investigate everything from the beginning, I give it as my opinion that all these things worthily harmonize with the predictions that Jesus is the Son of God. (Contra Celsum I.28)

The Greek word skotios carries the meaning 'bastard' and this keyword is interesting because in the TY tradition Jesus has been referred to by the cognate Hebrew (or Aramaic) words zimmâ or mamzer and also the expression ben/ bar niddâ which indicates that Miriam (Mary) was not yet purified from her menstruation when a villain made love with her or raped her. ${ }^{9}$ In I.32 by paraphrasing Celsus' text Origen informs us more about Celsus' Jew who accounts for the circumstances in which Jesus was born. On this occasion the name of

struction we must take into account how Origen has quoted his source, that is, Celsus' critical treatise on Christianity. Scholars often answer this methodological case by noting that Origen, in many points, has cited his source verbatim even though he may also have shortened Celsus' text. Nor did he always give a very precise picture of Celsus' arguments. See, e.g., Thomas 2006: $72-3$.

9 A woman is impure for seven days after she has menstruated all blood (Lev. I5:19-30). This detail has been used as an argument that Jesus was born in circumstances which were not according to the instructions of the Torah. See further Lockshin I993: 2264I, esp. 235. 
Jesus' father is given as Panthera (I.32; the name Panthera is also mentioned in I.33, 69): ${ }^{10}$

But let us now return to where the Jew is introduced, speaking of the mother of Jesus, and saying that when she was pregnant she was turned out of doors by the carpenter to whom she had been betrothed, as having been guilty of adultery, and that she bore a child to a certain soldier named Panthera; and let us see whether those who have blindly concocted these fables about the adultery of the Virgin with Panthera, and her rejection by the carpenter, did not invent these stories to overturn His miraculous conception by the Holy Ghost: for they could have falsified the history in a different manner, on account of its extremely miraculous character, and not have admitted, as it were against their will, that Jesus was born of no ordinary human marriage. It was to be expected, indeed, that those who would not believe the miraculous birth of Jesus would invent some falsehood. And their not doing this in a credible manner, but (their) preserving the fact that it was not by Joseph that the Virgin conceived Jesus, rendered the falsehood very palpable to those who can understand and detect such inventions.

The name of Panthera is significant because in rabbinical writings (e.g. Tosefta Hullin II.24; bShabb I 04b), ${ }^{11}$ as well as in the Toledot Yeshu tradition, the name Pandira or Pantira has been used. Two of the earliest versions of the Toledot Yeshu tradition, the so-called early Yemenite and the Byzantine version, contain the birth story of Jesus (Meerson and Schäfer 20I4, I: I47-66; II: 65-78). ${ }^{12}$ The early Yemenite text calls Jesus Yeshu ben Pandera ha-Notsri and adds the attribute zimmâ $\hat{u} b a r$ niddâ, 'abomination (bastard) and the son of

10 I.69: 'But he [Celsus] disbelieves the accounts of His conception by the Holy Ghost, and believes that He was begotten by one Panthera, who corrupted the Virgin, because a god's body would not have been so generated as you were. But we have spoken of these matters at greater length in the preceding pages.'

11 Concerning the interpretation of bShab ro4b see Schäfer 2007: I 5-24 where it is also noted that the rabbinic term is parallel to Celsus' 'Jewish' tradition of Panthera. See further mShabb I 2:4; tShabb i i: I 5 ; yShabb I 2:4/3. Note also Johann Maier's (I 978: 249-67) evaluation of the origin of the Jesus ben Pandira tradition.

12 It is significant that the Early Oriental B version (New York JTS 8998) does not contain the birth story of Jesus, but nevertheless the manuscript begins with reference to Jesus as the son of Pandera: 'This is the Book of the Nazoreans, as decreed concerning Yeshuac $^{c}$, the son of Pandera'. See Meerson and Schäfer 20I4, I: I37-44. The Early Oriental A manuscripts and the Early Oriental C are both fragmentary at the beginning (Meerson and Schäfer 20 I 4, I: I 2 7-36, I45-6) so we do not know whether or not the birth story has been recounted in them. 
menstruating woman'. The story begins with the observation of how rabbis realize that Jesus was interested in gambling. They want to know more about this man and so Rabbi Yehoshuac ben Perahiah receives information from the mother of Jesus. She tells the following story which explains the expression zimmâ ûbar niddâ: 'Once I went out at night to launder my shawls after menstruation and I still was impure. Then, someone approached me, and I did not recognize him, and he raped me, and so I conceived this boy.' This being the case the story connects the name of the father of Jesus with the rapist who violated the mother of Jesus during her period of menstrual impurity. The story continues to characterize the mother of Jesus in the follow-

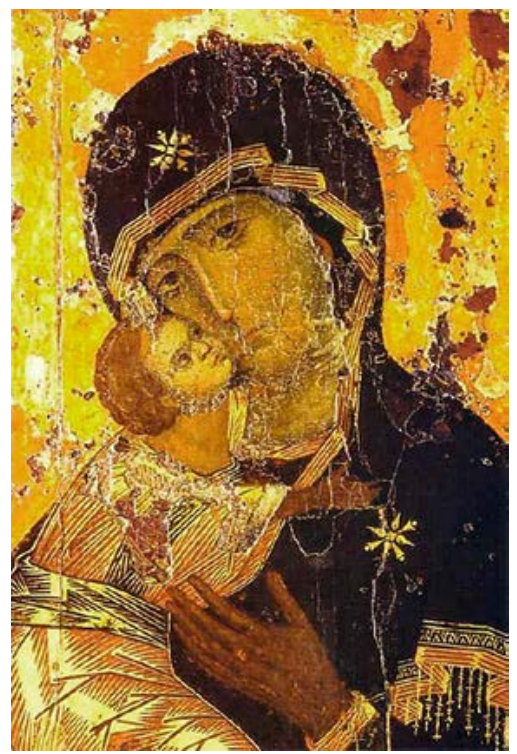

Our Lady of Vladimir, twelfth century, the holy protectress of Russia, now in the Tretyakov Gallery. Wikimedia Commons. ing way: 'And the mother of Yeshu was an extremely important woman, although a frivolous one, and because she used to go out alone without (a man) who would keep her safe, she brought this misfortune upon herself.' The early Yemenite version does not mention anything about the father of Yeshu, but implies his name in the introductory words of the text: 'The story of Yeshu ben Pandera ha-Notsri (may his name and memory be blotted out), who was an abomination and the son of a menstruating woman.'

The Byzantine version also contains a story of rape but in this case the story begins with a positive characterization of Miriam and Yosef. Yosef 'feared God more than most people in his generation'. But one day he quarrelled with a Jew who decided to destroy Yosef by committing adultery with his wife. One Sabbath eve this wicked man 'climbed into his [Yosef's] bed and lay with Miriam, who thought that he was her husband Yosef'. She became pregnant and Yosef later noticed this. It became clear for him and then also Miriam what had taken place but 'from his great love for Miriam, for she was very [beautiful] he did not reveal what happened, so that the matter would not have to go before a court'. The story is certainly ironical in assuming that Miriam made love without recognizing who the man was, and Yosef who feared God after all did not reject adulterous Miriam. The story then goes on to tell how Yosef, Miriam and Yeshu went to Egypt and how Miriam had more children 
there 'again by harlotry (biznît), more than once' and how Yeshu learned there 'Egyptian wisdom, in illusions and sorcery'. In this connection the story states that 'they called him Yeshuc the son of Yosef'. Only later in the story is Yeshu called 'ben Pandera' indicating again the way in which the name of the father has been interpreted in this Toledot Yeshu version. The Byzantine version may imply a schism between Yosef and Miriam, especially when it notes that in Egypt Miriam had more children as a result of harlotry. ${ }^{13}$ It is interesting that such a separation between Joseph and Mary is accounted in Celsus' texts (I.28, 32) already quoted and we may also add I.39:

I do not think it necessary to grapple with an argument advanced not in a serious but in a scoffing spirit, such as the following: 'If the mother of Jesus was beautiful, then the god whose nature is not to love a corruptible body, had intercourse with her because she was beautiful'; or, 'It was improbable that the god would entertain a passion for her, because she was neither rich nor of royal rank, seeing no one, even of her neighbours, knew her'. And it is in the same scoffing spirit that he adds: 'When hated by her husband, and turned out of doors, she was not saved by divine power, nor was her story believed. Such things', he says, 'have no connection with the kingdom of heaven'. In what respect does such language differ from that of those who pour abuse on others on the public streets, and whose words are unworthy of any serious attention?

Interestingly these paraphrases from Celsus' Jewish source (I.28, 32, 39) reveal two important points about Jesus and his parents which were later developed in the Toledot Yeshu tradition. Mary was beautiful and she was actually rejected by Joseph. ${ }^{14}$ This rejection implies that the birth of Jesus was an argument for his not having anything to do with the kingdom of heaven (I.39). ${ }^{15}$

13 In later Toledot Yeshu versions Yosef actually leaves Miriam because of her harlotry with Pandera.

14 The text which Origen quotes states that Mary was 'hated' (misoumenē) by Joseph. The expression 'hate' is, in fact, a juridical term in Jewish divorce documents as can be seen from the evidence of Elefantine papyri. For this see Bammel I 986: 270-I.

15 When Celsus uses this Semitic expression 'kingdom of heaven' (appears also in III.59; VI.I 7; VIII.r I) we may assume that it originates from the Gospels and could well be a part of his Jewish source which contains critical evaluations of Gospel stories. On the other hand, as Günter Stemberger has noted to me in an e-mail (I 7.5.201 5), the 'kingdom of heaven' is customary in rabbinic texts and can also originate from Jewish contexts. 
Finally, it should be noted that the Early Oriental B version characterizes Miriam by means of an expression which indicates that she was a prostitute: 'Her name is Miriam, and she grows the (long) hair of women'. ${ }^{16}$ In addition, the story accounts the words of Yeshu: 'I am a Jew, and also a bastard (mamzer)', as well as 'the name of my father was Pandera, and he was a foreigner in Israel', indicating that the Early Oriental B version parallels with Celsus's counterexegesis in Contra Celsum I.32 (so also Meerson and Schäfer 2014, I: I38ng).

\section{The picture of Mary in the early versions of Toledot Yeshu tradition}

I have argued above that the tradition of Celsus accords well with the evidence of rabbinical writings and TY tradition. Nevertheless, it is significant that Meerson and Schäfer argue that none of 'the earliest versions of Toledot Yeshu develop the story described by Celsus'. They continue that 'in fact, all early texts of Toledot Yeshu in the East and the West completely ignore the question of Yeshu's origin except for the single fact that he is "ben/bar Pandera" which alone does not imply much. Not a word about Yeshu's pedigree is said by the Aramaic fragments (the Early Oriental A and C) and the passage in Agobard.' ${ }^{17}$ If this is the case, then TY tradition would be an example of how the picture of Mary was transmitted differently in Jewish contexts where the aim was to oppose the virgin birth. After examining the early versions of TY literature I have come to a different conclusion.

All five versions in Group I available now in Meerson and Schäfer TY refer to Jesus as the son of Pandera. That the concept of 'the son of Pandera' is related to the adulterous origin of Jesus in the Talmud is noted by Schäfer (2007: I9). So it is difficult to see why the situation would have been different in the TY tradition where this concept has been used from earlier versions onwards. The Early Oriental $\mathrm{A}$ and $\mathrm{C}$ versions are fragmentary at the beginning (as presented in Meerson's and Schäfer's edition) and it is impossible to know whether or not they contained the birth narrative. On the other hand, the Early Oriental $\mathrm{B}$ version indicates clearly that Miriam was regarded as a prostitute and Jesus as a bastard. Therefore, we have good reason to argue that something similar was stated at the beginning of the Early Oriental A and C. The Yemenite version blames Miriam because she 'used to go out alone' (the point is that there were no witnesses to the rape and Miriam could have fabricated a convenient story about her pregnancy) and the Byzantine version states that Miriam made

16 Concerning this metaphor see bShabb ro4b and bErub roob and Schäfer 2007: I6-ı 8.

17 Meerson and Schäfer 20I4, I: 45-56. Both quotations are from p. 47. 
love with a man without recognizing who he really was - a detail which must be a parodic element. In addition, the Byzantine version notes that Miriam later had more children in Egypt 'again by harlotry, more than once', reiterating what happened the first time. This being the case, it is difficult for me to regard the early Yemenite version as one which 'contrasts with' the Early Oriental B version (in the case of Jesus' birth) as noted by Meerson and Schäfer (2014, I: I3 $8 \mathrm{ng}$ ). Rather they are good parallels to each other.

We can hardly use Agobard's references as an argument that Jesus' adulterous birth was unknown in early TY versions. After all, Agobard only recounts Jewish stories as he heard them from those who knew Hebrew (as noted in Schäfer 20I r: 27-48, esp. p. 38). In addition, Agobard's successor Amulo (as noted by Schäfer) referred to Jewish ideas about the origin of Jesus: "he is impious and the son of an impious, namely (someone), of uncertain origin, whom they call Pandera: with whom they say the mother of (our) Lord committed adultery, and in this way he, in whom we believe, was born. ${ }^{18}$ So it is hardly possible that such a detail was lacking in TY versions in Agobard's time.

This being the case the only relevant conclusion is that Miriam was regarded more or less as a prostitute or an adulterous woman in the early versions of TY. No sympathetic view of Miriam can be detected. ${ }^{19}$ In the counter-narratives such as TY the main point was to show the falsehood of the Christian concept of the virgin birth of Jesus. Miriam's pregnancy is recounted in the early TY versions in quite a similar way as is found in Celsus' counter-exegetical themes of the life of Jesus.

The early versions of TY indicate how they have related the birth story of Jesus to the name Pandera. It is clear that the 'ben Pandera' tradition is something which has been transmitted in rabbinical circles. It denoted the suspicious origin of Jesus in a similar way to Celsus' counter-exegesis. But the historical details of this suspicious origin were not clearly indicated in rabbinical traditions which opened up the possibility of developing different explanations, as

18 This is noted in Schäfer 20I I: 45-6. It is worth noting that Schäfer writes on p. 47: 'Although we cannot know whether Amulo had access to Celsus (through Origen) or - admittedly less likely - to the Babylonian Talmud's brief reference to Pandera as Miriam's lover, one thing seems clear: Amulo's Toledot Yeshu was focused on Jesus' death and not in his birth and life.' However, the Early Oriental B version is a nice parallel to Amulo's version because it contains ideas that Jesus is a bastard, the son of an adulterous relationship between Miriam and Pandera.

19 For a sympathetic view of Miriam, see Gager and Ahuvia 2013. 
is already indicated in early versions of TY (belonging to Group I). In later texts (Group II and III) there were more sophisticated variations. ${ }^{20}$

An attempt to date the history of the Panthera tradition earlier than Celsus gives us no firm results. As does Justin Martyr (Dial 43, 50, 63, 67) so does also Origen (I.34) discuss Isa. 7:14 and the meaning of the Hebrew word 'almâ (translated parthenos in LXX). While arguments presented in Justin's and Origen's texts are similar, the former never refers to the alleged 'Jewish' story concerning Panthera as the father of Jesus. Acts of Pilate II.3. is another early text which contains reference to the illegitimate birth of Jesus as expressed by his Jewish opponents: 'you were born of fornication'. Nevertheless, the date of Acts of Pilate cannot be firmly traced back to earlier than the beginning of the fourth century. ${ }^{21}$

This being the case, we have a coherent interpretive tradition from the Jewish points of view which depicts the pregnancy of Mary as an adulterous act, presumably with the Jewish villain Pandira or the Roman soldier Panthera. Could it be possible that a similar interpretive scenario was already countered in the Gospels of Matthew and Luke?

\section{Apology for Virgin Mary in the Gospel of Matthew}

Felix Scheidweiler has suggested that the genealogy of Matthew may indicate that scurrilous rumours about the birth of Jesus prevailed (among the Jews). The genealogy in Matt. I mentions four women each of whom were - in some ways - suspicious cases in the Hebrew Bible: Tamar (gave birth as a consequence of harlotry, Gen. 38), Rahab (was a harlot, Josh. 2 and 6), Ruth (was a Moabite woman, see Deut. 23:4-5) and Batsheba (committed adultery with David, 2 Sam. I I-I 2). ${ }^{22}$ These four examples are listed in the Gospel of

20 For different versions of Toledot Yeshu note Alexander 201 r: 588-6r6. He is well aware of the fact that scholars should wait for the publication of all Toledot Yeshu manuscripts. Nevertheless, he has made several important remarks on this tradition.

21 See the text and its date in Scheidweiler 199r. Scheidweiler notes that Epiphanius (about 375/6) clearly refers to Acts of Pilate and, therefore, it certainly existed at that time, apparently even earlier. The problem is that there are different references to texts where Pilate plays a role and their relation to the Acts of Pilate remains unclear.

22 According to Origen, Celsus maintained in his work that Christians have fabricated the genealogies of Jesus (II.32): 'But he asserts that the "framers of the genealogies, from a feeling of pride, made Jesus out to be descended from the first man, and from the kings of the Jews". And he thinks that he makes a notable charge when he adds, that "the carpenter's wife could not have been ignorant of the fact, had she been of such illustrious descent".' 
Matthew in order to explain why it is no wonder that in the case of Mary and the infant Jesus there are also rumours concerning Jesus' origin.

At first sight the case of Ruth seems to be an exception. Even though she was a Moabite woman she nevertheless had a good reputation. However, it is worth noting that Deut. 23:4-5 excludes Moabites from the community of Israel. In addition, just before these verses there is a statement (Deut. 23:3) that no bastard (mamzer) can be taken into the congregation of God. It is precisely this verse which has been used in the Byzantine version of TY to argue the case that Jesus cannot be accepted in the congregation. ${ }^{23}$ So what we have in

23 Meerson and Schäfer 2014, I: I 56: 'They said to him this, A bastard shall not enter the congregation of God (Deut. 23:2 [sic]). He said to them, "And even if it were as you say, I am wiser than you and fear the Lord, and I will not hold back his rebuke from you, You shall surely rebuke your kinsman" (Lev. I 9: I 7 ). They replied to him, "From now on, we will not accept your words, and you will not even dwell among us, because you are a bastard." He tried to appease them, but they did not relent until he gave in and went away in his zeal. And Jeroboam turned to evil ways.'While a modern reader may find sympathetic elements in the story and regard the Jews here as being in the wrong in this case, the point is that there was something fundamentally amiss in Jesus' behaviour. The earlier Byzantine story noted that Jesus learned 'Egyptian wisdom, in illusions and sorcery' and this explains why he was so wise. While Christians may argue that Jesus' wisdom was due to his divinity and his supernatural birth was therefore set in high relief, the Toledot Yeshu tradition argues, as it were, parodically, that Jesus was indeed wise, but this was due to his being a bastard and having escaped to Egypt with his mother (who continued her harlotry there); there he learned magic and sorcery. It is worth quoting Origen, Contra Celsum I.33 who argues that the birth of Jesus must be supernatural: 'Now if a particular soul, for certain mysterious reasons, is not deserving of being placed in the body of a wholly irrational being, nor yet in that of one purely rational, but is clothed with a monstrous body, so that reason cannot discharge its functions in one so fashioned, which has the head disproportioned to the other parts, and altogether too short; and another receives such a body that the soul is a little more rational than the other; and another still more so, the nature of the body counteracting to a greater or less degree the reception of the reasoning principle; why should there not be also some soul which receives an altogether miraculous body, possessing some qualities common to those of other men, so that it may be able to pass through life with them, but possessing also some quality of superiority, so that the soul may be able to remain untainted by sin? And if there be any truth in the doctrine of the physiognomists, whether Zopyrus, or Loxus, or Polemon, or any other who wrote on such a subject, and who profess to know in some wonderful way that all bodies are adapted to the habits of the souls, must there have been for that soul which was to dwell with miraculous power among men, and work mighty deeds, a body produced, as Celsus thinks, by an act of adultery between Panthera and the Virgin?! Why, from such unhallowed intercourse there must rather have been brought forth some fool to do injury to mankind - a teacher of licentiousness and wickedness, and other evils; and not of temperance, and righteousness, and the other virtues!' 




Hortus Deliciarum, Der Stammbaum Christi, C. 1180. Herrad von Landsberg, CC-BY-SA 3.0, Wikimedia Commons. 
Matthew I is clearly an attempt at an apology for the Virgin Mary. Her pregnancy was not due to harlotry. On the other hand, scurrilous rumours against her can be explained typologically. There are many other women in the lineage from Abraham to the Messiah whose bad reputation has not obsructed the historical salvation plans of God.

In order to argue that the virgin birth was indeed part of an essential plan of salvation Matthew uses Isa. 7:I 4 which in the Septuagint translation refers to the virgin (parthenos) who will give birth to the son whose name is Immanuel (meaning 'God is with us'). The rumours concerning Mary and her pregnancy almost led to her rejection by Joseph, but this proof based on prophecy confirmed to him that the pregnancy of Mary was part of the divine plan. At the end of the Gospel the reference is made anew to the Immanuel prophecy (Matt. 28:18-20). Jesus promised to be among his disciples. He really is Immanuel; 'God is with us'.

Another important detail in the Gospel of Matthew is the description of the manner in which the virgin birth of Jesus is presented. The writer never refers to the 'Father', but rather the Holy Spirit (so also in the Gospel of Luke). There is reason to believe that this way of speaking about the virgin birth is based on the traditions formulated in Hebrew or in Aramaic where the Spirit is grammatically feminine. In this way the early Christians expressed the birth of Jesus in terms which distanced it from the idea of a sexual act between Mary and the divine masculine power. In that way also the blasphemy (with an association to Gen. 6:I-4) was avoided. However, I Tim. 3:I6 indicates that the Christians even had to encounter the criticism that Jesus' (virgin) birth was demonic event.

\section{Apology for the virgin birth in 1 Tim. 3:16}

Jukka Thurén (2008: 5 I2-I5) argues that I Tim. 3:I6 speaks about the incarnation of Jesus in a way which contrasts it with the interpretation of Gen. 6:I-4 in the First Book of Henoch. He remarks that in I Tim. 3:9 the writer speaks about 'the mystery of belief' but in I Tim. 3: 6 he uses a parallel term, 'the mystery of godliness':

Beyond all question, the mystery of godliness is great (mega estin to tês eusebeias mystêrion):

He appeared in the flesh, was justified by the Spirit, was seen by angels, 
was preached among the nations, was believed in in the world, was taken up in glory.

Where has the writer taken this parallel expression 'the mystery of godliness' from? According to Thurén, an attractive possibility is that the writer wants to contrast the incarnation of Jesus with I Henoch 8, according to which the fallen angels came from Heaven and revealed all kinds of ungodliness (asebeia) to human beings. The Letter of Jude refers to I Henoch, probably to I Hen. I:9 (Jude I4) and, in addition, mentions the fallen angels as salutary examples to its readers. In the Letter of Jude Christians are warned four times about asebeia ( $\left.\mathrm{vv}_{4}, \mathrm{I}_{5}[2 \mathrm{x}], \mathrm{I} 8\right)$ indicating that the Greek word is a key concept in the letter. I am inclined to interpret I Tim. 3: I 6 in such a way that it provides a counterargument for those who have understood the birth of Jesus to be an example of the scenario outlined in Gen. 6:I-4; that is, the way in which the son of God sinned with Mary and gave birth to a demonic Jesus.

I Tim. 3: 6 explains why it was difficult to speak about the miraculous pregnancy of Mary, performed by the divine power. Such an idea was associated with the activity of the sons of God in Gen. 6:I-4. Once some Christians had found a way of expressing the virgin birth of Jesus with reference to the Holy Spirit (a feminine word in the Hebrew language) it was easier to begin to speak about the pregnancy of Mary. This apparently took place quite early because two strikingly different traditions of the infancy stories were recounted in Matthew I-2 and Luke I-2. Nevertheless, both writers have the same theological emphasis: Jesus was born to the Virgin Mary whose pregnancy was due to creative action on the part of the Holy Spirit. It is significant that such a tradition was not adopted in the Gospel of John (written later than Matthew and Luke's gospels) and a good explanation for this is that the writer deliberately avoided referring to the virgin birth of Jesus. He estimated that such a concept would come dangerously close to Genesis 6.

\section{Incarnate wisdom:}

\section{an alternative way of speaking about the miraculous birth of Jesus}

So far I have proposed that there were theological problems relating to the virgin birth of Jesus. Every explanation which suggests that God was in some way an active agent in the birth of Jesus would have immediately evoked Gen. 6:I-4, which was interpreted in Jewish writings (the Book of Jubilees and the First Book of Henoch) as an explanation of the origin of the demonic 
world. ${ }^{24}$ Therefore, the first Christians resorted to other ways of speaking about the incarnation of the Son of God. This explanation was based on Proverbs 8:22-3I, according to which a personification of Wisdom assisted God in the creation. It was argued that this personified Wisdom was the Son of God (r Cor. 8:6; Col. I:I4-I 8; John I:I-3; Heb. г:I-3) and this Son of God became a human being ( $\mathrm{Gal} \mathrm{4:4}$; Phil. 2:7). Both expressions 'born of a woman' in Gal. 4:4 and 'taking the very nature of a servant, being made in human likeness' in Phil. 2:7 are Semitic ways of saying that the Son of God became a human being. The Christological formulation in Rom. I:3-4 should not be interpreted to mean that the title of 'Son of God' would be given to Jesus only after the resurrection. Its aim was to emphasize that after his resurrection Jesus was made Son of God in power - an idea which was based on Ps. 2:7. This Old Testament passage was interpreted in the New Testament as referring to the resurrection of Jesus (Acts I $3: 32-3$ ). As the Davidic prince (the potential king) had once, during his enthronement ceremony, acquired a powerful position next to God and became an actual king, so also in Rom. I:3-4 Jesus is depicted as the son of David who through resurrection becomes a powerful king next to God, a Son of God in power (Ps. 2:7 and I IO:I). ${ }^{25}$ It is obvious that early Christians (such as Paul) believed that the birth of Jesus was in some way extraordinary, particularly if Jesus was regarded as a personification of the Wisdom of God through whom the world was created (earliest evidence is I Cor. 8:6).

\section{Conclusions}

Scholars often explain the birth stories of the Gospels of Matthew and Luke as later attempts to explain the origin of Jesus in terms of the concept of the virgin birth. This may be true as far as the formulation of the virgin birth taking place with the aid of Holy Spirit is concerned. On the other hand, it is more difficult to argue that the birth of Jesus would have been understood as

24 It is worth noting that Celsus' Jew, who apparently knew the Gospel of Matthew and its presentation of the virgin birth of Jesus, nevertheless presents it in terms of God making love to Mary (I.39): 'If the mother of Jesus was beautiful, then the god whose nature is not to love a corruptible body, had intercourse with her because she was beautiful'; or, 'It was improbable that the god would entertain a passion for her, because she was neither rich nor of royal rank, seeing no one, even of her neighbours, knew her.'

25 For this common understanding of Rom. $1: 3-4$, that Jesus was already the incarnate Son of God before his death and was made Son of God in power through resurrection, see e.g. Wilckens 1978: 64-6. Concerning the traditio-historical background of Rom. I:3-4, see Eskola 1992. 
miraculous only in the time of Matthew and Luke onwards. After all, the concept that Jesus was the Son of God and Wisdom incarnate (Prov. 8; I Cor. 8:6; Col. I:I 5-20; John I:I-3; Heb. I:I-3) must have contained some sorts of ideas concerning how Jesus was born. And as far as I can see, the birth of Jesus was in some way regarded as miraculous in this Christological model, too.

In this article I have argued that the virgin birth of Jesus was the target of two sorts of criticism. The first of these was related to negative rumours or even parodies of how Mary became pregnant. The parodies in the Toledot Yeshu literature and Celsus' Panthera episode were post-New Testament traditions, but I have suggested that in the genealogy of the Gospel of Matthew there are negative rumours concerning the pregnancy of Mary, as indicated in Matt. I:I 8-I 9. Other references in the Gospels indicate that similar rumours may have alluded to Jesus who is referred to only as the son of Mary (Mark 6:3; Matt. 13:55-6; John $\mathrm{I}: 45,6: 42$ ). Origen thought along similar lines when he argues that Mary and close family members of Jesus had to hide Mary's pregnancy in order to avoid scandal. Origen presents the following historical scenario in his Homilies on the Gospel of Luke (only preserved in Latin) when he interprets the passage of Ignatios (Eph. I 9:I-3), concerning the meaning of the words principem saeculi buius latuit virginitas Mariae ('the virginity of Mary was hidden from the prince of this world') and explains them: latuit propter Ioseph, latuit propter nuptias, latuit quia habere virum putabatur ('hidden for the sake of Joseph, hidden for the sake of marriage, hidden because it was believed that she had a husband'). ${ }^{26}$

Secondly, I have proposed that I Tim. 3:I6 was an answer to the criticism that the virgin birth of Jesus must be interpreted as some sort of demonic event, according to the model of Gen. 6:I-4. In this criticism Mary's pregnancy is seen as being the work of a demonic angel or similar monster. It was precisely this problem which led to the alternative way of speaking about the birth of Jesus. According to this model Jesus was God's Wisdom (the Son of God) who was incarnated and became human. This model is followed in the earliest documents of the New Testament, that is, in the letters of Paul as well as in one of the latest New Testament documents - the Gospel of John. Both Matthew and Luke were courageous enough to formulate the idea of the virgin birth by using an older Hebrew or Aramaic tradition according to which it was the (feminine) Holy Spirit not God the Father which was active in the pregnancy of Mary. 
Antti Laato is a professor in Old Testament Exegetics and Judaic Studies at Åbo Akademi University. He is the leader of the international SRB (Studies in the Reception History of the Bible) network which examines how biblical traditions have been transmitted in the three Abrahamic monotheistic religions. His SRB-related research project Where are you, Adam? A New Understanding of Adam in Jewish-Christian-Muslim Context has received finance from the Academy of Finland (2013-17). He has recently published the monographs Who is the Servant of the Lord? Jewish and Christian Interpretations on Isaiah 53 from Antiquity to the Middle Ages (SRB 4, Eisenbrauns 2012) and Guide to Biblical Chronology (Sheffield Phoenix Press 2015).

\section{Bibliography}

Alexander, Philip, 20 I I. 'Jesus and his mother in the Jewish anti-Gospel (the Toledot Yeshu)' in Infancy Gospel: Stories and Identities, eds Claire Clivaz, Andreas Dettwiler, Luc Devillers, and Enrico Norelli with Benjamin Bertho, Wissenschaftliche Untersuchungen Neuen Testament, 28 I (Tübingen, Mohr Siebeck), pp. 588-6 I6

Bader, Robert, I940. Der alēthēs logos des Celsus, Tübinger Beiträge zur

Altertumswissenschaft, 33 (Stuttgart, Berlin)

Bammel, Ernst, I986. 'Der Jude des Celsus' in Judaica. Kleine Schriften, I, ed. Ernst

Bammel, Wissenschaftliche Untersuchungen Neuen Testament, 37 (Tübingen, Mohr Siebeck), pp. 265-83

Baumgarten, Albert, I 990. 'Jews, pagans and Christians on the empty grave of Jesus' in Proceedings of the Tenth World Congress of Jewish Studies Division B, vol. 2: The History of the Jewish People (Jerusalem, World Union of Jewish Studies), pp. 37-44

Bhayro, Siam, 2005. The Shemihazah and Asael Narrative of 1 Enoch 6-11. Introduction, Text, Translation and Commentary with Reference to Ancient Near Eastern and Biblical Antecedents, Alter Orient und Altes Testament, 322 (Munich, Ugarit-Verlag)

2006. 'Noah's library: sources for I Enoch 6-I I', Journal for the Study of Pseudepigrapha, I 5, pp. I63-77

Biale, David, I999. 'Counter-history and Jewish polemics against Christianity: the Sefer Toldot Yeshu and the Sefer Zerubavel, Jerwish Social Studies, 6, pp. I $30-45$

Blummell, Lincoln, 2007. 'A Jew in Celsus': True Doctrine? An examination of Jewish anti-Christian polemic in the second century CE', Studies in Religion, 36, pp. 297-3I 5

Brown, Raymond, I 993. The Birth of the Messiab: A Commentary on the Infancy Narratives in the Gospels of Matthew and Luke, The Anchor Yale Bible Reference Library (New York, Doubleday)

Chadwick, Henry, I 953. Origen: Contra Celsum (Cambridge University Press)

Crouzel, Henri, I 962. Homélies sur S. Luc, Sources Chrétiennes, 87 (Paris)

Eskola, Timo, I 992. Messias ja Jumalan poika. Traditiokriittinen tutkimus kristologisesta jaksosta Room. 1:3,4 (Helsinki, Suomen eksegeettinen seura) 
Fröhlich, Ida, and Erkki Koskenniemi, 2013. Evil and the Devil, Library of New

Testament Studies, 48 I (London, Bloomsbury)

Funkenstein, Amos, r 993. Perceptions of Jewish History (Berkeley, University of California Press)

Gager, John, and Mika Ahuvia, 2013. 'Some notes on Jesus and his parents: from the

New Testament Gospels to the Toledot Yeshu' in Envisioning Judaism: Studies in

Honor of Peter Schäfer on the Occasion of his Seventieth Birthday, vol. 2, eds Ra'anan S. Boustan, Klaus Herrmann, Reimund Leicht, Annette Y.

Reed, and Giuseppe Veltri, in collaboration of Alex Ramos (Tübingen, Mohr

Siebeck), pp. 997-Ior 9

Gambero, Luigi, I 999. Mary and the Fathers of the Church: The Blessed Virgin Mary in Patristic Though (San Fransisco, Ignatius Press)

Hanson, Paul, I 977. 'Rebellion in Heaven, Azazel, and euhemeristic heroes in I Enoch 6-I I', Journal of Biblical Literature, 96, pp. I95-233

Hargis, Jeffrey, I 999. Against Christians: The Rise of Early Anti-Christian Polemic (New York, Peter Lang)

Hengel, Martin, I 992. 'Christological titles in Early Christianity' in The Messiah:

Developments in Earliest Judaism and Christianity. The First Princeton Symposium on Judaism and Christian Origins, ed. James H. Charlesworth (Minneapolis, Fortress), pp. 425-48

Hoffman, Joseph, 1987. Celsus On the True Doctrine: A Discourse Against the Christians (Oxford University Press)

Krauss, Samuel, I 902. Das Leben Jesu nach jüdischen Quellen (Berlin, Calvary)

Lange, Nicholas de, 1978. Origen and the Jerws: Studies in Jerwish-Christian Relations in Third-Century Palestine (Cambridge University Press)

Lockshin, Martin, I 993. 'Translation as polemic: the case of Toledot Yeshu' in Minhah le-Nahum: Biblical and Others Studies Presented to Nahum M. Sarna in Honor of his 70th Birthday, eds Marc Brettler and Michael Fishbane, JSOT Supplement, I 54 (Sheffield Academic Press), pp. 226-4I

Lona, Horacio, 2005. Die "wahre Lehre" des Celsus (Freiburg, Herder)

Maier, Johann, I 978. Jesus von Nazareth in der talmudischen Überlieferung (Darmstadt, Wissenschaftliche Buchgesellschaft)

Matlock, Barry, 2000. 'The birth of Jesus and why Paul was in favour of it' in The Birth of Jesus, ed. G. J. Brooke (Edinburgh, T\&T Clark), pp. 45-57

Meerson, Michael, and Peter Schäfer, 20 I 4. Toledoth Yeshu: The Life Story of Jesus, 2 vols., Texts and Studies in Ancient Judaism, I 59 (Tübingen, Mohr Siebeck)

Nickelsburg, George, I 977. 'Apocalyptic and myth in I Enoch 6-I I', Journal of Biblical Literature, 96, pp. 383-405

Niehoff, Maren, 2013. 'A Jewish critique of Christianity from second-century Alexandria: revisiting the Jew mentioned in Contra Celsum', Journal of Eastern Christian Studies, 2 I, pp. I 5 I-75

Rokéah, David, 2002. Justin Martyr and the Jews (Leiden, Brill) 
Schäfer, Peter, 2007. Jesus in the Talmud (Princeton University Press)

-20 I I. 'Agobard's and Amulo's Toledot Yeshu' in Toledot Yeshu ("The Life Story of Jesus") Revisited, eds Peter Schäfer, Michael Meerson, and Yaacov Deutsch, Texts and Studies in Ancient Judaism, I 43 (Tübingen, Mohr Siebeck), pp. 27-48

Schäfer, Peter, Michael Meerson, and Yaacov Deutsch, 20 I r. Toledot Yeshu ("The Life Story of Jesus") Revisited, Texts and Studies in Ancient Judaism, I 43 (Tübingen, Mohr Siebeck)

Scheidweiler, Felix, r 991. '3. The Gospel of Nicodemus, Acts of Pilate and Christ's descent into Hell' in New Testament Apocrypha I: Gospels and Related Writings, ed. Wilhelm Schneemelcher (Westminster, John Knox), pp. 50 I-36

Schreckenberg, Heinz, I 999. Die christlichen Adversus-Judaeos-Texte und ibr literarisches und historisches Umfeld (1.-11.Jh.), Europäische Hochschulschriften, 23: I 72 (Frankfurt am Main, Peter Lang)

Thomas, S. 2006. 'Celsus' in $A-Z$ of Origen, ed. John Anthony McGuckin (London, The SCM Press 2006), pp. 72-3

Thurén, Jukka, 2008. Korinttilaiskirjeet, Tessalonikalaiskirjeet, Paimenkirjeet (Helsinki, Kustannus oy Arkki)

Triggs, Joseph, I 998. Origen (London, Routledge)

VanderKam, James, r 999. 'The angel story in the book of Jubilees' in Pseudepigraphic Perspectives: The Apocrypha and Pseudepigrapha in Light of the Dead Sea Scrolls. Proceedings of the International Symposium of the Orion Center for the Study of the Dead Sea Scrolls and Associated Literature, 12-14 January, eds Estelle G. Chazon and Michael E. Stone, Studies on the Texts of the Desert of Judah, 3 I (Leiden, Brill), pp. I 5 I -70

Wilckens, Ulrich, I 978. Der Brief an die Römer (Röm 1-5), Evangelisch-Katholischer Kommentar zum Neuen Testament, VI: (Zürich, Benziger Verlag)

Zellentin, Holger, 20 I I. Rabbinic Parodies of Jerwish and Christian Literature, Texts and Studies in Ancient Judaism, I 39 (Tübingen, Mohr Siebeck) 